$\Phi=\Phi$

\title{
Impact on post partum amenorrhoea beyond breastfeeding
}

\author{
A. K. Shukla ${ }^{1 *}$, A. K. Tiwari $^{2}$, R. C. Yadava ${ }^{3}$ \\ ${ }^{1}$ Assistant Professor Department of Community Medicine Subharti Medical College \\ Swami Vivekanad Subharti University, Meerut-250005 (UP) India \\ ${ }^{2}$ Faculty Member IBS Business School ICFAI University Dehardun India \\ ${ }^{3}$ Department of Statistics Banaras Hindu University (BHU) Varanasi India \\ *Corresponding author E-mail: arvindshukla_vns@rediffmail.com
}

\begin{abstract}
Citing various studies Bongaarts (1980) has concluded that breastfeeding is the principal determinant of post partum amenorrhoea (PPA) and unrestricted breastfeeding is associated with lower fertility. On the other hand many researchers have shown opposite views by saying that other factors are also responsible in affecting the duration of PPA. In this paper, we have investigated the relationship between the two duration variables viz. PPA and breastfeeding utilizing data of NFHS-2. For this purpose, we have controlled the duration of breastfeeding and then investigated whether distribution of PPA duration shows similar pattern in different situations or it varies with the situations. This can help in deciding whether PPA duration is mainly affected by breastfeeding or some other factors are also operating in shaping its distribution. In this context, we show that even after controlling the duration of breastfeeding (keeping breastfeeding at least six months) the percentage of females having PPA duration less than four months, shows large variation according to caste, educational level, standard of living index (SLI) and body mass index (BMI) of females. If breastfeeding would have been the only principal determinant of duration of PPA, this percentage should have remained almost constant! This shows that some other factors beyond breastfeeding are responsible for shaping the distribution of PPA duration of a female.
\end{abstract}

Keywords: Post Partum Amenorrhoea (PPA); Body Mass Index; NFHS; SLI.

\section{Introduction}

The duration of post partum amenorrhoea (PPA) is the period taken to return of menses following a live birth or late term of abortion or still birth? This is temporary infecundable period during which a woman is non-susceptible to pregnancy again due to suspension of natural cycle of ovulation and menstruation and the attainment of first menstruation is treated as the termination of PPA.

Fertility is basically a biological phenomenon very much influenced by a large number of socio-cultural and behavioral factors. This fact greatly complicates the analysis of the effect of the biological factors on fertility.

Among the many biological factors affecting human fertility, duration of PPA plays a dominant role in shaping the fertility behavior of a population. It is extensively reported that breastfeeding is the major determinant of prolonged PPA, in societies where it is nearly universal, prolonged, and of high intensity (Santow, 1987; Howie and McNeilly,1982; Habicht et al., 1985; Akin et al., 1986; Huffman et al., 1987; Srinivasan et al., 1989; Savina and Kennedy, 1989; Nath et al., 1993; Singh et al., 1994). Many researchers have pointed out that breastfeeding is the only dominant factor influencing the PPA and especially nutrition does not play any significant role on it (Bongaarts, 1980). This conclusion is mainly based on the results obtained in Choudhary (1978), Huffman et al. (1978) Bongaarts and Delgado (1979) etc. It is because of this fact that Bongaarts (1978) has considered duration of breastfeeding as one of the important proximate determinants of fertility.

On the other hand, opposite views have been reported by many other researchers (Chebez and Maliner, 1973; Huffman et al.,
1987; Prema et al., 1981; Lune et al., 1981; ICMR 1995; Diezet et al., 1998; Yadav et. al., 2005). The authors have shown that better nutrition is responsible for shortening the duration of PPA. Many researchers have shown that several socio-economic, demographic and cultural factors affect the length of PPA (Delgado et al., 1982; Habicht et al., 1985; Singh and Singh, 1989; Singh et al., 1990; Nath et al., 1993; Singh et al., 1994). Most of these results are based on data of limited areas and sample sizes are also not reasonably large.

In the National Family Health Survey (NFHS), extensive data have been collected on durations of post partum amenrrhoea (PPA) as well as breastfeeding for births occurring during last three or four years. Such data provide great opportunities to investigate the relationship between the two duration variables. Most of the studies have shown that there is strong positive relationship between two variables. However, still the view is quite open whether duration of breastfeeding is the only dominant variable influencing PPA or there are some other factors also which play significant role on determining PPA. The objective of the present paper is to throw some light on this complicated issue. For this purpose data of NFHS-2 for various major states have been utilized to investigate the nature of relationship as well as variation (if any) in the spatial pattern in the country.

\section{Data}

The National Family Health Survey (NFHS) was carried out as the principal activity of a collaborative project to strengthen the research capabilities of the Population Research Centers in India, initiated by the Ministry of Health and Family Welfare, Govern- 
ment of India, and coordinated by the International Institute for Population Sciences, Mumbai. There have been two rounds of the survey conducted. (Recently the third round of NFHS has also been completed but detailed results are still awaited). The first round of NFHS was conducted in 1992-93 (NFHS-1) while second round was undertaken in 1998-99 (NFHS-2). In the NFHS-2, data relating to current status of post partum amenorrhoea related to births occurring during last three years from the survey date have been obtained. Further, for the cases where post partum amenorrhoea is already completed, the duration of PPA have also been noted. These data constitute the basis of study in this paper.

\section{Methodology and results and discussion}

The NFHS report has already provided estimates of median duration of breastfeeding as well as PPA period for different states of the country. These are presented here as table 1 .

A look at this table clearly indicates that there is strong positive relationship between average (median) durations of breastfeeding and PPA. Is this much analysis adequate to conclude that duration of breastfeeding is a dominant factor affecting duration of PPA? The answer is perhaps "not".

We try to investigate the matter here in some alternative way. Such attempt has also been done by Yadav et. al. (2005). But the results are based on data from a very limited area and the sample size is also small. The whole idea behind this type of analysis is that if we fix the duration of breastfeeding and examine the behavior of duration of PPA, the results may give some clues. Consequently we have fixed the duration of breastfeeding (at least six months) and then compare the proportion of births where duration of PPA is less than four months. For all such cases, where the PPA period is ceased, breastfeeding was still continuing and all births have occurred at least six months prior to survey date. Thus if breastfeeding is the only dominant factor affecting PPA period, then these proportions should be almost constant for all groups of the population.

We have computed such proportions (in percentages) for different groups of the major states of the country classified according to caste category, religion, area of residence, educational level, body mass index (BMI) and standard of living index (SLI).

These results are shown in table 2 to 15 for states of Uttar Pradesh, Madhya Pradesh, Rajasthan, Bihar, Orissa, Punjab, Tamil Nadu, Kerala, Karnataka, Andhra Pradesh, Maharashtra, Gujarat, West Bengal and India as a 'whole'.

A close look on these tables reveals interesting and curious results. First of all there is large variation in this proportion across different groups in all the states of the country, the lowest being less than 15\% (Karnataka and Andhra Pradesh) to maximum being near 70\% (Punjab). We must remember that these estimated percentages are not based on smaller samples.

The other important feature can be seen from the following fact: Definitely standard of living index (SLI), body mass index (BMI) and educational level of females can be considered to be high correlates of social, economic and nutritional development of females under consideration. When we observe the computed percentages for different groups it is fond that

i) As BMI increases, by and large the proportion also increases constantly in all states.

ii) As SLI increases the above pattern emerges for all the states.

iii) Similar results are also found when we consider the educational level of females.

iv) Similar situation also occurs when we observe the percentages according to caste groups. It is minimum for SC/ST in all the states where as the maximum is observed for 'Other caste'. The OBC's lie in between the two. Similar is the position of these groups as for as their social, economic and nutritional status are concerned. v) When we observe the rural-urban differentials in this percentage, the lower values are observed for rural areas in all the states.

These results clearly indicate that better economic and nutritional development is responsible for shortening the duration of PPA because increase in the percentage of PPA period less than four months will be responsible for lowering the average period of PPA

These results have been obtained on the condition that everywhere duration of breastfeeding is more than six months. This implies that breastfeeding has no role in altering these proportions. Thus the obvious conclusion may be that some factor (s) beyond breastfeeding is/are playing significant role on shaping the behavior of PPA period. From the above discussion it seems that perhaps nutrition may be a dominant determinant of this proportion because $\mathrm{BMI}$ is considered to be a good indicator of nutritional status of a female.

The other important finding is that although the above pattern is almost universal but the economically most developed state of Punjab shows very high proportions (percentages) in comparison to less developed states like Orissa, Uttar Pradesh and Bihar for the same groups. For example, in Punjab for BMI>25.0, this percentage is 71.4 where as in the same group for Orissa, Uttar Pradesh and Bihar this is around 50\%. The reasons are not very much clear but perhaps better nutritional status in this group in Punjab in comparison to other states may be responsible for such a pattern or some other factors such as food habits or other environmental or behavioral factors may be responsible for this phenomenon. This needs further investigations.

We have also analyzed the data according to religion. Only the two religions have been considered as Hindu and Muslim (except in Punjab where the two religions are Hindu and Sikh). In this case no uniform pattern is seen over the states. However, in majority of states, Hindus show lower percentage for PPA period less then four months in comparison to Muslims (India, Kerala, Tamil Nadu, Punjab, Gujarat, Maharashtra, Karnataka, Andhra Pradesh, Madhya Pradesh and Bihar). The opposite trend is observed for Rajasthan and Orissa. However the percentage for Hindus and Muslims are almost equal in case of Uttar Pradesh and West Bengal. In Punjab, Hindus show higher percentage than Sikhs.

\section{Conclusion}

Bongaarts (1980) concluded that breastfeeding was the principal determinant of PPA, and unrestricted breastfeeding was associated with lower fertility. The results obtained in this paper clearly indicate that even after controlling the duration of breastfeeding (keeping breastfeeding at least six months) the percentage of females having PPA duration less than four months, shows large variation according to caste educational level, SLI and BMI of female. This clearly indicates that some other factors beyond breastfeeding are responsible for shaping the distribution of PPA duration of a female.

Table 1: Median Duration of Breastfeeding and Post Partum Amenorrhoea (PPA) by States, NFHS-2, (1998-1999)

\begin{tabular}{lcc}
\hline States & $\begin{array}{c}\text { Median duration of } \\
\text { Breastfeeding }\end{array}$ & $\begin{array}{c}\text { Median duration } \\
\text { of PPA }\end{array}$ \\
\hline Kerala & 24.5 & 4.0 \\
Tamil Nadu & 16.1 & 5.1 \\
Punjab & 21.2 & 5.4 \\
West Bengal & $\geq 36$ & 6.7 \\
Gujrat & 22.0 & 7.5 \\
Maharastra & 23.8 & 7.7 \\
Karnataka & 20.0 & 8.0 \\
Rajsthan & 25.5 & 8.5 \\
Orissa & $\geq 36$ & 8.7 \\
Uttar Pradesh & 25.8 & 9.0 \\
Andhra Pradesh & 25.0 & 9.5 \\
Madhya Pradesh & $\geq 36$ & 10.3 \\
Bihar & $\geq 36$ & 11.3 \\
INDIA & $\mathbf{2 5 . 4}$ & $\mathbf{8 . 6}$ \\
\hline
\end{tabular}


Table 2: Percentage of Females Whose PPA Less Than Four Months (and Breastfeeding Duration Is More Than Six Months) and Median Duration of PPA According to Different Characteristics, INDIA, NFHS-2

\begin{tabular}{|c|c|c|}
\hline Characteristics & $\begin{array}{l}\text { Percentage of females } \\
\text { (whose PPA }<4 \text { months, when BF }>6 \text { ) }\end{array}$ & $\begin{array}{l}\text { Median duration of } \\
\text { PPA (in months) }\end{array}$ \\
\hline Total & 29.2 & 8.2 \\
\hline \multicolumn{3}{|l|}{ Caste } \\
\hline $\mathrm{SC} / \mathrm{ST}$ & 23.3 & 10.2 \\
\hline $\mathrm{OBC}$ & 29.0 & 8.2 \\
\hline Others & 34.5 & 6.6 \\
\hline \multicolumn{3}{|l|}{ Religion } \\
\hline Hindu & 28.2 & 8.3 \\
\hline Muslim & 32.2 & 6.9 \\
\hline \multicolumn{3}{|l|}{ Place of Residence } \\
\hline Rural & 26.6 & 8.7 \\
\hline Urban & 38.3 & 6.0 \\
\hline \multicolumn{3}{|l|}{ Education } \\
\hline Illiterate & 24.1 & 10.8 \\
\hline Literate (less than middle) & 30.5 & 6.8 \\
\hline Middle to high school & 36.2 & 6.2 \\
\hline Above high school & 44.5 & 4.4 \\
\hline \multicolumn{3}{|l|}{ Body Mass Index } \\
\hline$<18.5$ & 24.9 & 10.1 \\
\hline $18.5-20.0$ & 27.9 & 8.3 \\
\hline $20.0-25.0$ & 34.6 & 6.5 \\
\hline$>25.0$ & 46.9 & 4.3 \\
\hline \multicolumn{3}{|c|}{ Standard of Living Index } \\
\hline Low & 21.3 & 12.1 \\
\hline Medium & 29.9 & 6.9 \\
\hline High & 45.8 & 4.4 \\
\hline
\end{tabular}

Table 3: Percentage of Females Whose PPA Less Than Four Months (And Breastfeeding Duration Is More Than Six Months) and Median Duration of PPA According To Different Characteristics, Kerala, NFHS-2

\begin{tabular}{|c|c|c|}
\hline Characteristics & $\begin{array}{l}\text { Percentage of females } \\
\text { (whose PPA }<4 \text { months, when BF>6) }\end{array}$ & $\begin{array}{l}\text { Median duration of } \\
\text { PPA (in months) }\end{array}$ \\
\hline Total & 45.9 & 4.5 \\
\hline \multicolumn{3}{|l|}{ Caste } \\
\hline SC/ST & 38.1 & 6.3 \\
\hline OBC & 53.5 & 2.9 \\
\hline Others & 49.4 & 4.1 \\
\hline \multicolumn{3}{|l|}{ Religion } \\
\hline Hindu & 45.9 & 4.5 \\
\hline Muslim & 50.5 & 3.0 \\
\hline \multicolumn{3}{|l|}{ Place of Residence } \\
\hline Rural & 49.4 & 4.0 \\
\hline Urban & 51.6 & 3.0 \\
\hline \multicolumn{3}{|l|}{ Education } \\
\hline Illiterate & 32.0 & 8.3 \\
\hline Literate (less than middle) & 45.7 & 4.6 \\
\hline Middle to high school & 54.9 & 2.9 \\
\hline above high school & 52.2 & 2.9 \\
\hline \multicolumn{3}{|l|}{ Body Mass Index } \\
\hline$<18.5$ & 43.8 & 3.9 \\
\hline $18.5-20.0$ & 49.3 & 4.1 \\
\hline $20.0-25.0$ & 54.5 & 2.9 \\
\hline$>25.0$ & 51.8 & 3.0 \\
\hline \multicolumn{3}{|c|}{ Standard of Living Index } \\
\hline Low & 41.1 & 6.1 \\
\hline Medium & 25.3 & 6.9 \\
\hline High & 58.8 & 2.8 \\
\hline
\end{tabular}

Table 4: Percentage of Females Whose PPA Less Than Four Months (And Breastfeeding Duration Is More Than Six Months) and Median Duration of PPA According to Different Characteristics, Tamil Nadu, NFHS-2

\begin{tabular}{lcl}
\hline Characteristics & $\begin{array}{l}\text { Percentage of females } \\
\text { (whose PPA<4months, when BF>6) }\end{array}$ & $\begin{array}{l}\text { Median duration of } \\
\text { PPA (in months) }\end{array}$ \\
\hline Total & 33.8 & 6.2 \\
Caste & & \\
SC/ST & 26.7 & 6.7 \\
OBC & 36.1 & 6.0 \\
Others & 54.4 & 2.8 \\
Religion & & \\
Hindu & 32.7 & 6.2 \\
Muslim & 42.8 & 4.5 \\
Place of Residence & & \\
Rural & 29.9 & 6.4 \\
Urban & 41.7 & 4.7 \\
Education & & \\
Illiterate & 28.0 & 6.7 \\
Literate (less than middle) & 32.2 & 6.5 \\
Middle to high school & 38.6 & 4.6 \\
Above high school & 43.9 & 4.4 \\
Body Mass Index & & \\
<18.5 & 30.7 & 6.4 \\
18.5-20.0 & 25.9 & 6.3 \\
20.0-25.0 & 37.0 & 6.1 \\
>25.0 & 51.1 & 3.0 \\
Standard of Living Index & 6.1 \\
Low & 25.5 & \\
Medium & 37.6 & \\
High & 47.7 & \\
\hline & & \\
\hline
\end{tabular}

Table 5: Percentage of Females Whose PPA Less Than Four Months (And Breastfeeding Duration Is More Than Six Months) and Median Duration of PPA According to Different Characteristics, Punjab, NFHS-2

\begin{tabular}{|c|c|c|}
\hline Characteristics & $\begin{array}{l}\text { Percentage of females } \\
\text { (whose PPA }<4 \text { months, when BF }>6 \text { ) }\end{array}$ & $\begin{array}{l}\text { Median duration of } \\
\text { PPA (in months) } \\
\end{array}$ \\
\hline Total & 59.4 & 2.7 \\
\hline \multicolumn{3}{|l|}{ Caste } \\
\hline $\mathrm{SC} / \mathrm{ST}$ & 52.0 & 2.9 \\
\hline $\mathrm{OBC}$ & 58.6 & 2.7 \\
\hline Others & 65.1 & 2.6 \\
\hline \multicolumn{3}{|l|}{ Religion } \\
\hline Hindu & 57.9 & 2.8 \\
\hline Sikh & 51.8 & 2.9 \\
\hline \multicolumn{3}{|l|}{ Place of Residence } \\
\hline Rural & 57.8 & 2.7 \\
\hline Urban & 64.2 & 2.4 \\
\hline \multicolumn{3}{|l|}{ Education } \\
\hline Illiterate & 54.6 & 2.8 \\
\hline Literate (less than middle) & 50.4 & 3.0 \\
\hline Middle to high school & 57.4 & 2.7 \\
\hline Above high school & 69.4 & 2.3 \\
\hline \multicolumn{3}{|l|}{ Body Mass Index } \\
\hline$<18.5$ & 47.6 & 4.3 \\
\hline $18.5-20.0$ & 61.3 & 2.7 \\
\hline $20.0-25.0$ & 61.2 & 2.6 \\
\hline$>25.0$ & 71.4 & 2.4 \\
\hline \multicolumn{3}{|c|}{ Standard of Living Index } \\
\hline Low & 42.4 & 4.6 \\
\hline Medium & 51.8 & 2.9 \\
\hline High & 67.8 & 2.4 \\
\hline
\end{tabular}


Table 6: Percentage of Females Whose PPA Less Than Four Months (And Breastfeeding Duration Is More Than Six Months) and Median Duration of PPA According to Different Characteristics, West Bengal, NFHS-2

\begin{tabular}{|c|c|c|}
\hline Characteristics & $\begin{array}{l}\text { Percentage of females } \\
\text { (whose PPA<4months, when BF>6) }\end{array}$ & $\begin{array}{l}\text { Median duration of } \\
\text { PPA (in months) }\end{array}$ \\
\hline Total & 28.5 & 8.0 \\
\hline \multicolumn{3}{|l|}{ Caste } \\
\hline $\mathrm{SC} / \mathrm{ST}$ & 23.4 & 8.7 \\
\hline $\mathrm{OBC}$ & 26.4 & 8.8 \\
\hline Others & 31.8 & 6.8 \\
\hline \multicolumn{3}{|l|}{ Religion } \\
\hline Hindu & 28.8 & 6.8 \\
\hline Muslim & 26.3 & 8.6 \\
\hline \multicolumn{3}{|l|}{ Place of Residence } \\
\hline Rural & 25.0 & 8.6 \\
\hline Urban & 45.4 & 4.3 \\
\hline \multicolumn{3}{|l|}{ Education } \\
\hline Illiterate & 22.0 & 12.0 \\
\hline Literate (less than middle) & 32.6 & 6.7 \\
\hline Middle to high school & 33.3 & 6.4 \\
\hline Above high school & 46.9 & 4.1 \\
\hline \multicolumn{3}{|l|}{ Body Mass Index } \\
\hline$<18.5$ & 23.4 & 8.9 \\
\hline $18.5-20.0$ & 31.7 & 8.1 \\
\hline $20.0-25.0$ & 35.5 & 6.0 \\
\hline$>25.0$ & 41.7 & 4.5 \\
\hline \multicolumn{3}{|c|}{ Standard of Living Index } \\
\hline Low & 21.6 & 12.0 \\
\hline Medium & 33.1 & 6.4 \\
\hline High & 51.3 & 3.0 \\
\hline
\end{tabular}

Table 7: Percentage of Females Whose PPA Less Than Four Months (And Breastfeeding Duration Is More Than Six Months) and Median Duration of PPA According to Different Characteristics, Gujarat, NFHS-2
Table 8: Percentage of Females Whose PPA Less Than Four Months (And Breastfeeding Duration Is More Than Six Months) and Median Duration of PPA According To Different Characteristics, Maharastra, NFHS-2

\begin{tabular}{|c|c|c|}
\hline Characteristics & $\begin{array}{l}\begin{array}{l}\text { Percentage of females } \\
\text { (whose PPA }<4 \text { months, when BF }>6 \text { ) }\end{array} \\
\end{array}$ & $\begin{array}{l}\text { Median duration of PPA } \\
\text { (in months) }\end{array}$ \\
\hline Total & 24.5 & 8.6 \\
\hline \multicolumn{3}{|l|}{ Caste } \\
\hline $\mathrm{SC} / \mathrm{ST}$ & 20.3 & 8.5 \\
\hline $\mathrm{OBC}$ & 21.9 & 8.3 \\
\hline Others & 28.0 & 7.0 \\
\hline \multicolumn{3}{|l|}{ Religion } \\
\hline Hindu & 24.3 & 8.4 \\
\hline Muslim & 28.6 & 6.6 \\
\hline \multicolumn{3}{|l|}{ Place of Residence } \\
\hline Rural & 19.6 & 9.0 \\
\hline Urban & 22.5 & 6.4 \\
\hline \multicolumn{3}{|l|}{ Education } \\
\hline Illiterate & 19.6 & 12.1 \\
\hline Literate (less than middle) & 23.9 & 8.4 \\
\hline Middle to high school & 23.8 & 7.0 \\
\hline above high school & 36.8 & 6.0 \\
\hline \multicolumn{3}{|l|}{ Body Mass Index } \\
\hline$<18.5$ & 22.0 & 8.6 \\
\hline $18.5-20.0$ & 14.5 & 8.9 \\
\hline $20.0-25.0$ & 34.1 & 6.5 \\
\hline$>25.0$ & 42.7 & 4.4 \\
\hline \multicolumn{3}{|c|}{ Standard of Living Index } \\
\hline Low & 15.5 & 12.1 \\
\hline Medium & 25.7 & 7.0 \\
\hline High & 38.9 & 5.0 \\
\hline
\end{tabular}

Table 9: Percentage of Females Whose PPA Less Than Four Months (And Breastfeeding Duration Is More Than Six Months) and Median Duration of PPA According to Different Characteristics, Karnataka, NFHS-2

\begin{tabular}{|c|c|c|c|c|c|}
\hline Characteristics & $\begin{array}{l}\text { Percentage of females } \\
\text { (whose PPA }<4 \text { months, when BF>6) }\end{array}$ & $\begin{array}{l}\text { Median duration of } \\
\text { PPA (in months) }\end{array}$ & Characteristics & $\begin{array}{l}\text { Percentage of females } \\
\text { (whose PPA } 4 \text { 4months, when BF>6) }\end{array}$ & $\begin{array}{l}\text { Median duration of } \\
\text { PPA (in months) }\end{array}$ \\
\hline Total & 32.2 & 6.8 & Total & 19.0 & 8.2 \\
\hline Caste & & & Caste & & \\
\hline SC/ST & 26.5 & 10.6 & SC/ST & 13.6 & 12.0 \\
\hline $\mathrm{OBC}$ & 28.7 & 8.1 & $\mathrm{OBC}$ & 18.9 & 8.1 \\
\hline Others & 39.7 & 4.8 & Others & 22.8 & 6.8 \\
\hline Religion & & & Religion & & \\
\hline Hindu & 31.0 & 7.0 & Hindu & 17.5 & 8.3 \\
\hline Muslim & 43.0 & 4.4 & Muslim & 22.4 & 8.1 \\
\hline \multicolumn{3}{|l|}{ Place of Residence } & \multicolumn{3}{|l|}{ Place of Residence } \\
\hline Rural & 26.5 & 9.0 & Rural & 16.2 & 8.6 \\
\hline Urban & 41.5 & 4.8 & Urban & 25.5 & 6.6 \\
\hline \multicolumn{3}{|l|}{ Education } & \multicolumn{3}{|l|}{ Education } \\
\hline Illiterate & 22.8 & 12.0 & Illiterate & 14.2 & 10.2 \\
\hline Literate (less than middle) & 34.9 & 8.3 & Literate (less than middle) & 20.7 & 8.3 \\
\hline Middle to high school & 38.3 & 6.0 & Middle to high school & 19.7 & 6.8 \\
\hline Above high school & 49.4 & 4.0 & Above high school & 28.5 & 6.3 \\
\hline \multicolumn{3}{|l|}{ Body Mass Index } & \multicolumn{3}{|l|}{ Body Mass Index } \\
\hline$<18.5$ & 24.5 & 10.6 & $<18.5$ & 15.6 & 8.9 \\
\hline $18.5-20.0$ & 30.5 & 8.7 & $18.5-20.0$ & 17.3 & 8.4 \\
\hline $20.0-25.0$ & 42.7 & 4.8 & $20.0-25.0$ & 23.3 & 6.7 \\
\hline$>25.0$ & 39.4 & 6.2 & $>25.0$ & 29.6 & 6.3 \\
\hline \multicolumn{3}{|c|}{ Standard of Living Index } & \multicolumn{3}{|c|}{ Standard of Living Index } \\
\hline Low & 19.7 & 12.4 & Low & 12.4 & 12.2 \\
\hline Medium & 33.1 & 6.7 & Medium & 19.4 & 7.0 \\
\hline High & 44.6 & 4.4 & High & 31.9 & 6.1 \\
\hline
\end{tabular}


Table 10: Percentage of Females Whose PPA Less Than Four Month (And Breastfeeding Duration Is More Than Six Months) and Median Duration of PPA According to Different Characteristics, Rajasthan, NFHS-2

\begin{tabular}{|c|c|c|}
\hline Characteristics & $\begin{array}{l}\text { Percentage of females } \\
\text { (whose PPA }<4 \text { months, when BF }>6 \text { ) }\end{array}$ & $\begin{array}{l}\text { Median duration of } \\
\text { PPA (in months) } \\
\end{array}$ \\
\hline Total & 33.8 & 6.9 \\
\hline \multicolumn{3}{|l|}{ Caste } \\
\hline $\mathrm{SC} / \mathrm{ST}$ & 27.7 & 8.9 \\
\hline OBC & 30.3 & 10.2 \\
\hline Others & 40.0 & 6.2 \\
\hline \multicolumn{3}{|l|}{ Religion } \\
\hline Hindu & 33.8 & 6.9 \\
\hline Muslim & 30.9 & 12.0 \\
\hline \multicolumn{3}{|l|}{ Place of Residence } \\
\hline Rural & 31.4 & 9.0 \\
\hline Urban & 44.3 & 4.6 \\
\hline \multicolumn{3}{|l|}{ Education } \\
\hline Illiterate & 30.0 & 8.8 \\
\hline Literate (less than middle) & 38.3 & 6.1 \\
\hline Middle to high school & 48.9 & 4.1 \\
\hline Above high school & 58.0 & 2.7 \\
\hline \multicolumn{3}{|l|}{ Body Mass Index } \\
\hline$<18.5$ & 31.0 & 8.8 \\
\hline $18.5-20.0$ & 34.7 & 7.0 \\
\hline $20.0-25.0$ & 34.6 & 6.6 \\
\hline$>25.0$ & 55.2 & 2.6 \\
\hline \multicolumn{3}{|c|}{ Standard of Living Index } \\
\hline Low & 27.5 & 8.9 \\
\hline Medium & 31.7 & 8.6 \\
\hline High & 46.9 & 4.3 \\
\hline
\end{tabular}

Table 11: Percentage of Females Whose PPA Less Than Four Month (And Breastfeeding Duration Is More Than Six Months) and Median Duration of PPA According to Different Characteristics, Orissa, NFHS-2

\begin{tabular}{|c|c|c|}
\hline Characteristics & $\begin{array}{l}\text { Percentage of females } \\
\text { (whose PPA }<4 \text { months, when BF }>6 \text { ) }\end{array}$ & $\begin{array}{l}\begin{array}{l}\text { Median duration } \\
\text { of PPA (in months) }\end{array} \\
\end{array}$ \\
\hline Total & 23.2 & 8.9 \\
\hline \multicolumn{3}{|l|}{ Caste } \\
\hline $\mathrm{SC} / \mathrm{ST}$ & 17.8 & 12.0 \\
\hline $\mathrm{OBC}$ & 24.0 & 8.7 \\
\hline Others & 31.6 & 6.5 \\
\hline \multicolumn{3}{|l|}{ Religion } \\
\hline Hindu & 23.4 & 8.8 \\
\hline Muslim & 12.5 & 14.1 \\
\hline \multicolumn{3}{|l|}{ Place of Residence } \\
\hline Rural & 22.5 & 8.9 \\
\hline Urban & 29.5 & 8.2 \\
\hline \multicolumn{3}{|l|}{ Education } \\
\hline Illiterate & 26.2 & 10.4 \\
\hline Literate (less than middle) & 25.9 & 8.0 \\
\hline Middle to high school & 30.6 & 6.6 \\
\hline above high school & 40.7 & 4.8 \\
\hline \multicolumn{3}{|l|}{ Body Mass Index } \\
\hline$<18.5$ & 21.7 & 10.4 \\
\hline $18.5-20.0$ & 24.2 & 8.9 \\
\hline $20.0-25.0$ & 25.6 & 6.9 \\
\hline$>25.0$ & 44.5 & 4.5 \\
\hline \multicolumn{3}{|c|}{ Standard of Living Index } \\
\hline Low & 19.1 & 12.0 \\
\hline Medium & 25.5 & 8.1 \\
\hline High & 39.4 & 5.0 \\
\hline
\end{tabular}

Table 12: Percentage of Females Whose PPA Less Than Four Months (And Breastfeeding Duration Is More Than Six Months) and Median Duration of PPA According to Different Characteristics, Uttar Pradesh, NFHS-2

\begin{tabular}{|c|c|c|}
\hline Characteristics & $\begin{array}{l}\begin{array}{l}\text { Percentage of females } \\
\text { (whose PPA }<4 \text { months, when BF }>6 \text { ) }\end{array} \\
\end{array}$ & $\begin{array}{l}\text { Median duration of } \\
\text { PPA (in months) }\end{array}$ \\
\hline Total & 32.1 & 8.8 \\
\hline \multicolumn{3}{|l|}{ Caste } \\
\hline $\mathrm{SC} / \mathrm{ST}$ & 27.1 & 12.1 \\
\hline $\mathrm{OBC}$ & 29.0 & 10.4 \\
\hline Others & 35.5 & 8.0 \\
\hline \multicolumn{3}{|l|}{ Religion } \\
\hline Hindu & 35.6 & 8.5 \\
\hline Muslim & 35.2 & 7.0 \\
\hline \multicolumn{3}{|l|}{ Place of Residence } \\
\hline Rural & 29.1 & 10.8 \\
\hline Urban & 40.7 & 6.2 \\
\hline \multicolumn{3}{|l|}{ Education } \\
\hline Illiterate & 27.2 & 12.1 \\
\hline Literate (less than middle) & 35.6 & 6.6 \\
\hline Middle to high school & 40.5 & 6.7 \\
\hline Above high school & 50.6 & 3.0 \\
\hline \multicolumn{3}{|l|}{ Body Mass Index } \\
\hline$<18.5$ & 30.4 & 10.4 \\
\hline $18.5-20.0$ & 30.0 & 9.0 \\
\hline $20.0-25.0$ & 37.6 & 6.8 \\
\hline$>25.0$ & 54.5 & 2.8 \\
\hline \multicolumn{3}{|c|}{ Standard of Living Index } \\
\hline Low & 24.9 & 12.2 \\
\hline Medium & 31.0 & 8.7 \\
\hline High & 47.9 & 4.3 \\
\hline
\end{tabular}

Table 13: Percentage of Females Whose PPA Less Than Four Months (And Breastfeeding Duration Is More Than Six Months) and Median Duration of PPA According to Different Characteristics, Andhra Pradesh, NFHS-2

\begin{tabular}{|c|c|c|}
\hline Characteristics & $\begin{array}{l}\text { Percentage of females } \\
\text { (whose PPA<4months, when BF>6) }\end{array}$ & $\begin{array}{l}\text { Median duration of } \\
\text { PPA (in months) }\end{array}$ \\
\hline Total & 17.1 & 8.3 \\
\hline \multicolumn{3}{|l|}{ Caste } \\
\hline $\mathrm{SC} / \mathrm{ST}$ & 12.7 & 10.2 \\
\hline OBC & 16.2 & 8.5 \\
\hline Others & 22.8 & 6.6 \\
\hline \multicolumn{3}{|l|}{ Religion } \\
\hline Hindu & 15.6 & 8.6 \\
\hline Muslim & 35.4 & 4.9 \\
\hline \multicolumn{3}{|l|}{ Place of Residence } \\
\hline Rural & 15.7 & 8.6 \\
\hline Urban & 21.2 & 6.7 \\
\hline \multicolumn{3}{|l|}{ Education } \\
\hline Illiterate & 11.0 & 10.1 \\
\hline Literate (less than middle) & 23.3 & 8.1 \\
\hline Middle to high school & 22.6 & 8.0 \\
\hline Above high school & 26.5 & 4.8 \\
\hline \multicolumn{3}{|l|}{ Body Mass Index } \\
\hline$<18.5$ & 14.0 & 10.2 \\
\hline $18.5-20.0$ & 15.4 & 8.3 \\
\hline $20.0-25.0$ & 24.1 & 6.3 \\
\hline$>25.0$ & 24.3 & 6.3 \\
\hline \multicolumn{3}{|c|}{ Standard of Living Index } \\
\hline Low & 11.1 & 10.7 \\
\hline Medium & 18.5 & 8.1 \\
\hline High & 27.8 & 4.8 \\
\hline
\end{tabular}


Table 14: Percentage of Females Whose PPA Less Than Four Month (And Breastfeeding Duration Is More Than Six Months) and Median Duration of PPA According to Different Characteristics, Madhya Pradesh, NFHS-2

\begin{tabular}{|c|c|c|}
\hline Characteristics & $\begin{array}{l}\text { Percentage of females } \\
\text { (whose PPA }<4 \text { months, when BF>6) }\end{array}$ & $\begin{array}{l}\text { Median duration of } \\
\text { PPA (in months) }\end{array}$ \\
\hline Total & 26.7 & 10.7 \\
\hline \multicolumn{3}{|l|}{ Caste } \\
\hline SC/ST & 17.6 & 12.4 \\
\hline $\mathrm{OBC}$ & 30.8 & 8.6 \\
\hline Others & 40.0 & 6.4 \\
\hline \multicolumn{3}{|l|}{ Religion } \\
\hline Hindu & 30.8 & 8.4 \\
\hline Muslim & 36.8 & 6.7 \\
\hline \multicolumn{3}{|l|}{ Place of Residence } \\
\hline Rural & 23.5 & 12.1 \\
\hline Urban & 36.6 & 7.4 \\
\hline \multicolumn{3}{|l|}{ Education } \\
\hline Illiterate & 21.9 & 12.3 \\
\hline Literate (less than middle) & 27.8 & 8.9 \\
\hline Middle to high school & 38.0 & 6.2 \\
\hline above high school & 48.2 & 4.2 \\
\hline \multicolumn{3}{|l|}{ Body Mass Index } \\
\hline$<18.5$ & 23.4 & 12.1 \\
\hline $18.5-20.0$ & 27.1 & 10.6 \\
\hline $20.0-25.0$ & 29.1 & 10.2 \\
\hline$>25.0$ & 48.9 & 4.5 \\
\hline \multicolumn{3}{|c|}{ Standard of Living Index } \\
\hline Low & 20.6 & 12.4 \\
\hline Medium & 24.8 & 12.0 \\
\hline High & 44.0 & 4.9 \\
\hline
\end{tabular}

Table 15: Percentage of Females Whose PPA Less Than Four Month (And Breastfeeding Duration Is More Than Six Months) and Median Duration of PPA According To Different Characteristics, Bihar, NFHS-2

\begin{tabular}{|c|c|c|}
\hline Characteristics & $\begin{array}{l}\text { Percentage of females } \\
\text { (whose PPA }<4 \text { months, when BF }>6 \text { ) }\end{array}$ & $\begin{array}{l}\text { Median duration } \\
\text { of PPA (in } \\
\text { months) }\end{array}$ \\
\hline Total & 32.4 & 6.1 \\
\hline \multicolumn{3}{|l|}{ Caste } \\
\hline $\mathrm{SC} / \mathrm{ST}$ & 24.7 & 12.3 \\
\hline $\mathrm{OBC}$ & 28.7 & 8.0 \\
\hline Others & 39.7 & 5.8 \\
\hline \multicolumn{3}{|l|}{ Religion } \\
\hline Hindu & 31.1 & 7.0 \\
\hline Muslim & 43.1 & 4.4 \\
\hline \multicolumn{3}{|l|}{ Place of Residence } \\
\hline Rural & 26.6 & 10.1 \\
\hline Urban & 41.5 & 4.8 \\
\hline \multicolumn{3}{|l|}{ Education } \\
\hline Illiterate & 24.0 & 10.7 \\
\hline Literate (less than middle) & 34.9 & 8.2 \\
\hline Middle to high school & 38.3 & 6.0 \\
\hline above high school & 42.0 & 4.7 \\
\hline \multicolumn{3}{|l|}{ Body Mass Index } \\
\hline$<18.5$ & 24.5 & 10.5 \\
\hline $18.5-20.0$ & 27.6 & 10.2 \\
\hline $20.0-25.0$ & 42.8 & 4.8 \\
\hline$>25.0$ & 38.4 & 6.1 \\
\hline \multicolumn{3}{|c|}{ Standard of Living Index } \\
\hline Low & 19.5 & 12.5 \\
\hline Medium & 34.3 & 6.6 \\
\hline High & 44.6 & 4.4 \\
\hline
\end{tabular}

[2] Bongaarts J. (1978): Framework for analysing the proximate determinants of fertility. Population Development Review vol. 4, pp.105-132. https://doi.org/10.2307/1972149.

[3] Bongaarts J. and Delgado H. (1979): Effects of nutritional status on fertility in rural Guatemala. In: J.A.Menken and H. Leridon(eds),Patterns and Determinents of natural fertility, Liege, Ordina, pp. 107-033.

[4] Bongaarts J. (1980): Does malnutrition affect fecundity? A summary of evidence. Science, vol.208 pp.564-569. https://doi.org/10.1126/science.7367878.

[5] Chevez A. and Matinez C. (1973): Nutrition and development of infants from poor rural area -Maternal nutrition and its consequences on fertility. Nutr. Rep. Int., vol. 7, pp. 1-4

[6] Chowdhury A.K.M.A. (1978): Effect of maternal nutriational status on fertility in rural Gwatemala. In: W.H. Mosley (ed.) Nutiation and human reproduction New York: pienum, pp. 401-409.

[7] Delgado H., Lechtig A., Martorell R., Brineman E. and Klein R.E. (1978): Nutration, location and postpartum amenorrhoea. American Journal of Clinical Nutrition, vol. 31, pp.322-327.

[8] Habicht,J.P. Davanzo, J.S., Butz, W.P. and Meyers, L. D., (1985) The contraceptive role of breastfeeding. Population Studies, vol. 39 pp.213-232. https://doi.org/10.1080/0032472031000141456.

[9] Howie P.W. and Mc Neilly A.S.(1982) Contraceptive effect of breast-feeding patterns on Human Birth Intervals.Journa; of Reproduction and Fertility vol.65, pp.545

[10] Huffman S.L., Chowdhury A.M.K., Chakraborty J. and Mosley W.H. (1978): Nutrition and post patrum amenorrhoea in rural Bangladesh. Population Studies, vol. 32 pp. 251-260 https://doi.org/10.1080/00324728.1978.10410713.

[11] Huffman S.L., Ford K., Allen H.A. and Streble, P. (1987) Nutrition and Fertility in Bengladesh: Breastfeeding and post partum amenorrhoea. Population Studies, vol. 41, pp.447-462. https://doi.org/10.1080/0032472031000142996.

[12] ICMR (1995): Lactation-current concepts and concerns ICMR Bulletin, vol. 25 (8), pp.73-80

[13] Nath D. C., Land K. C. and Singh K. K. (1994): The role of breastfeeding beyond postpartum amenorrhoea on the return of fertility in India: a life table and hazards model analysis Journal of Biosocial Science vol. 26, pp.191-206. https://doi.org/10.1017/S0021932000021234.

[14] Nath D. C., Singh K.K., Land K. C,Talukdar (1993):Breastfeeding and PPA in traditional society: A Hazards modal analysis. Social Biology vol.40, pp.74-86.

[15] National Family Health Survey 1998-1999, International Institute for Population Sciences, Mumbai, India.

[16] Prema K., Naidu N., Neelakumari S. and Ramalakshmi, B.A. (1981): Nutrition-fertility interaction in lactating women of lowincome groups. American Journal of Clinical Nutrition, vol. 45, pp.461-467. https://doi.org/10.1079/bjn19810124.

[17] Santow,G. (1987):Reassessing the cotraceptive effect of breastfeeding.population studies vol.41,pp.147

[18] Savina G. and Kennedy K. I. (1989): The effect of a breast-feeding education program on loctational amenrrhoea in the Philippines studies in Family planning vol 20 pp203-214.

[19] Singh K. K., Suchindran C. M. and Singh R. S. (1994): Smoothed Breastfeeding duration and waiting time: Social Biology vol 41(3,4), pp. 229-239.

[20] Singh S. N. and Singh K. K. (1989): Life table analysis of censored data on post partum amenorrhoea period. Demography India, vol. 18(1-2), 27-38.

[21] Singh S. N., Singh K. K, Singh K.(1990):Socio-economic development and transition in the duration of PPA. Survival function analysis of data, Janasamkhya vol. (8) pp. 41-54.

[22] Srinivasan K., Pathak K. B. and Pandey A. (1989): Determinants of breast-feeding and post partum amenorrhoea in Orissa. Journal of Biosocial Science vol. 21, pp. 365-371 https://doi.org/10.1017/s002193200001806x.

[23] Yadav S., Mishra C.P. and Srivastava P. (2005): Impact of Breastfeeding vis-à-vis Nutrition on Duration of Post Partum Amenorrhoea, Demography India, vol. 34 (2), pp. 233-239.

\section{References}

[1] Akin J.S., Billsborrow R. E. Guilkey D. K. and Popkin B. M (1986): "Breast-feeding Patterns and Determinants in the Near East: An Analysis for four countries" Population Studies. vol. 40 pp 247 262. https://doi.org/10.1080/0032472031000142056. 